\title{
The therapeutic potential of ROR $\gamma$ modulators in the treatment of human disease
}

\author{
This article was published in the following Dove Press journal: \\ Journal of Experimental Pharmacology \\ II October 2012 \\ Number of times this article has been viewed
}

\author{
Mi Ra Chang' \\ Devrishi Goswami' \\ Becky A Mercer ${ }^{2}$ \\ Patrick R Griffin ${ }^{1,2}$ \\ 'Department of Molecular \\ Therapeutics, Scripps Florida, The \\ Scripps Research Institute, Jupiter, \\ FL, USA; ${ }^{2}$ Translational Research \\ Institute, Scripps Florida, The Scripps \\ Research Institute, Jupiter, FL, USA
}

Correspondence: Patrick R Griffin The Scripps Research Institute, Scripps Florida, I 30 Scripps Way, \#2A2, Jupiter, FL 33458, USA

$\mathrm{Tel}+|56| 2282200$

Fax + I $56 \mid 228308$ I

Email pgriffin@scripps.edu

\begin{abstract}
Nuclear receptors (NR) are ligand-regulated transcription factors that bind DNA in proximity to their target genes and exert their effects as a result of binding by small molecule ligands such as sterols, lipids, fatty acids, retinoids, and steroid hormones. The retinoic acid receptor-related orphan receptors or RORs (NR1F1-NR1F3) are nuclear receptors that regulate multiple cellular processes, including metabolism, cellular differentiation, and apoptosis, in a range of tissues and organs. These receptors bind as monomers to ROR response elements commonly called ROREs present in promoter regions of target genes and tether chromatin remodeling enzymes, facilitating recruitment of transcription machinery. Several recent reports have highlighted the potential role for RORs in human disease, and more importantly, studies have demonstrated that these receptors can be modulated by exogenous synthetic ligands, paving the way for development of novel therapeutics. Here we review the current status of synthetic ligand development as well as the structural aspects governing modulation of ROR signaling pathways as they relate to metabolic diseases and autoimmune disorders.
\end{abstract}

Keywords: retinoic acid receptor-related orphan receptors (ROR), nuclear receptor (NR) modulator, synthetic ligand, inverse agonists, metabolic disorder, autoimmune disorder, ligandbinding domain (LBD)

\section{Introduction}

Members of the nuclear receptor (NR) superfamily regulate the expression of target genes involved in a range of physiological processes such as development, metabolism, and immunity. All members of the superfamily are multidomain proteins, with many consisting of a highly variable N-terminal "A/B domain" that contains a ligand-independent activation function domain (AF-1) that can engage transcriptional coregulators regardless of receptor-ligand status, a two zinc finger DNA-binding "C domain," a highly variable hinge "D domain," and an "E domain" ligand-binding domain (LBD) that contains the ligand-dependent activation function-2 cofactorbinding surface (Figure 1). ${ }^{1,2}$ Several NRs, such as the estrogen receptor, contain an additional C-terminal "F domain" whose functional role is poorly defined.

The LBDs of the nuclear receptors are multifunctional (eg, bind to ligands and interact with coregulators and coreceptors) and have the secondary domain structure (predominately $\alpha$-helical) that is characteristic of all NRs. While there are some NRs that likely do not bind ligands, most NRs activate or repress transcription of their target genes in response to binding small molecules or upon specific post-translational modifications. Endogenous NR ligands include small molecules such as fatty acids, bile acids, cholesterol metabolites, and steroid hormones. Synthetic ligands that function as 


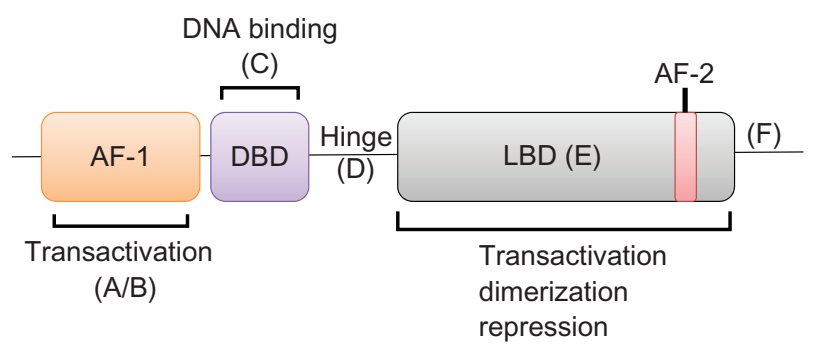

Figure I Canonical domain structure of nuclear receptors (NRs).

Notes: Most members of the nuclear receptor superfamily contain the following functional domains: an $\mathrm{N}$-terminal domain containing activation function I (AFI, also known as the $A / B$ domain), a highly conserved zinger finger containing DNA-binding domain or $C$ domain, a highly variable hinge or $\mathrm{D}$ domain, and a $\mathrm{C}$-terminal ligandbinding domain (LBD) or E domain that contains activation function 2 (AF2). Several NRs contain a highly variable C-terminal $\mathrm{F}$ domain.

activators (agonists that increase activity over basal levels), neutralizers (antagonists, that keep receptor activity at basal levels), and inhibitors or repressors (inverse agonists that lower activity below basal levels) have been developed for many of the NR family members. Several examples of such modulators are used clinically in the treatment of diabetes and dyslipidemia (NR1C1;PPAR $\alpha$ and NR1C3;PPAR $\gamma$ ), inflammation (NR3C1;GR), cancer (NR3C3;PR), and osteoporosis (NR3A1;ER $\alpha$ ).

Of the 48 genes in the human NR superfamily, several are still considered "orphan receptors" because their endogenous ligands have not yet been identified. For instance, the NR1F subfamily containing the retinoic acid receptor-related orphan receptors (RORs), named for their sequence homology to the retinoic acid receptor, referred to as RAR, are considered orphan receptors, although strong evidence has shown that these receptors potently bind to and are modulated by oxysterols. ${ }^{3}$ The ROR subfamily contains three major isoforms: ROR $\alpha$ (NR1F1), ROR $\beta$ (NR1F2), and ROR $\gamma$ (NR1F3). ${ }^{4-7}$ The RORs display significant sequence similarity, and each ROR gene generates several isoforms, differing only in their amino termini, as a consequence of alternative promoter usage and exon splicing. Four different ROR $\alpha$ isoforms have been shown to be expressed in lung, muscle, brain, heart, peripheral blood leukocytes, spleen, liver, and ovary. ${ }^{5,8}$ In contrast, ROR $\beta$ exhibits a more restricted neuronalspecific expression pattern in brain, retina, and pineal gland., ${ }^{5,9}$ ROR $\gamma$ has been shown to be highly expressed in thymus (the thymus-specific isoform is referred to as ROR $\gamma$ t), muscle, testis, pancreas, prostate, heart, and liver.

The RORs have been shown to bind to DNA as monomers on half-site elements with a $5^{\prime}$-A/T-rich extension, which is identical to the response elements of the orphan NRs known as the Rev-erbs. ${ }^{6,10}$ Like other NRs, the RORs have been shown to interact with transcriptional coactivators such as SRC1 (NCOA1), ${ }^{11}$ SRC2 (NCOA2 or TIF2), ${ }^{12} \mathrm{PGC} 1 \alpha,{ }^{13}$ and p300/ CBP, and with transcriptional corepressors such as NCOR1, SMRT (NCOR2), ${ }^{14}$ RIP140, ${ }^{15}$ and neuronal interacting factor $\mathrm{X}$ (NIX1) (Figure 2). ${ }^{16} \mathrm{ROR} \alpha$ is considered to be constitutively active, with the ability to interact with coregulatory proteins without the need to bind ligand. Structural studies have suggested that the coactivator-binding surface (AF2) of ROR $\alpha$ is locked in a holo or active conformation, ${ }^{17}$ circumventing the need for ligand binding to facilitate coactivator interaction. Interestingly, however, the co-crystal structures of ROR $\alpha$ LBD bound to cholesterol and cholesterol sulfate suggest that this receptor can bind to metabolites of cholesterol. ${ }^{18,19}$ It is not clear that these metabolites of cholesterol modulate the function of the receptor. Recent studies suggest that ROR $\gamma$ is not constitutively active but that this receptor requires binding to ligands such as 25-hydroxycholesterol (25-OHC) for activation and interaction with coregulators. ${ }^{20}$ While intriguing, the nature of the endogenous ligand for ROR $\gamma$ remains controversial. Regardless, we and others have shown that a range of oxysterols can potently bind to and modulate the function of ROR $\gamma .{ }^{20}$ The crystal structure of ROR $\beta$ bound with stearate in complex with a SRC1 LXXLL motif NR box peptide has been solved. ${ }^{21}$ The presence of stearate in the receptor's ligand-binding pocket (LBP) was described as an artifact of the protein expression system, as stearate has low affinity for ROR $\beta$ and this ligand does not modulate the activity of the receptor.

In 2010, it was shown that the LXR agonist T0901317 was a potent repressor (inverse agonist) of both ROR $\alpha$
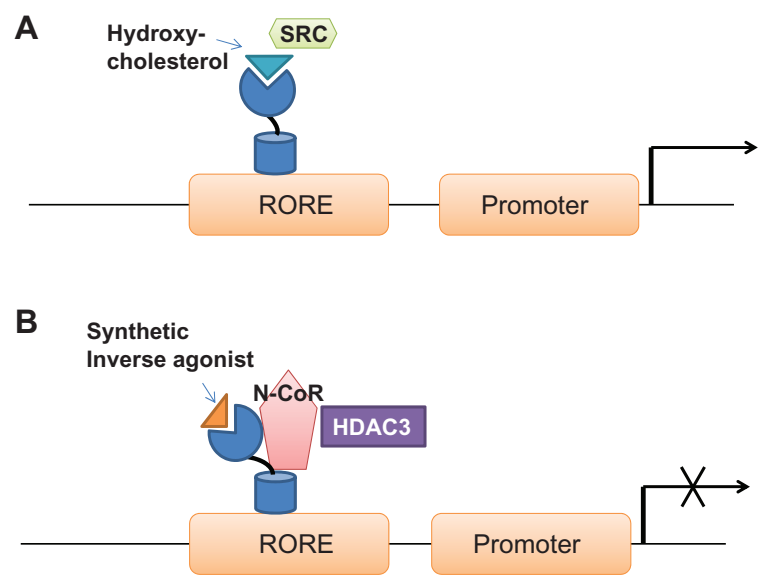

Figure 2 Mechanism of repression of RORs by synthetic ligands. (A) ROR agonists drive recruitment of transcriptional coactivators such as SRC2. (B) Inverse agonists of ROR displace coactivator and drive recruitment of transcriptional repressors. Abbreviations: SRC, steroid receptor coregulator; ROR, receptor-related orphan receptors; RORE, ROR respon element; NCoR, nuclear receptin co-repression; HDAC3, histone deacetylase. 
and ROR $\gamma{ }^{22}$ Interestingly, T0901317 does bind potently to the LBD of ROR $\beta$; however, in cotransfection assays, T0901317 did not modulate the activity of ROR $\beta$ (unpublished data). A caveat is that ROR $\beta$ has little to no constitutive activity when transfected into cells, so in these assays, it may not be possible to detect repression. More recently, selective synthetic modulators of ROR $\alpha$ and ROR $\gamma$ have been described, such as the ROR $\alpha$-selective inverse agonist SR3335, ${ }^{23}$ the dual ROR $\alpha /$ ROR $\gamma$ inverse agonist SR1001, ${ }^{24}$ and the ROR $\gamma$-selective inverse agonists SR155525 and SR2211. ${ }^{26}$ The natural products digoxin and ursolic acid have been described as ROR $\gamma$-selective inverse agonists. ${ }^{27,28}$ However, their utility as candidates for further development is limited, as digoxin displays significant adverse drug reactions with a very narrow therapeutic index, and ursolic acid activates other nuclear receptors. ${ }^{29,30}$ Surprisingly, unlike the advances made for ROR $\alpha$ and ROR $\gamma$, few advances have been made, to date, in the development of potent and selective modulators of ROR $\beta$.

\section{RORs in metabolic disease}

A role for ROR $\alpha$ in the regulation of metabolic pathways was revealed by studies in the staggerer $\left(\mathrm{ROR} \alpha^{\mathrm{sg}}\right.$ $\left.{ }^{\mathrm{sg}}\right)$ mouse. ${ }^{31,32}$ This natural mutant mouse strain carries an intragenic insertion within the $\mathrm{ROR} \alpha$ gene that results in a frame shift and a premature stop codon causing the ROR $\alpha$ protein to be inactive. Staggerer mice are less susceptible to hepatic steatosis and have a lower body fat index relative to wild-type mice, despite their having higher food consumption. A role for ROR $\alpha$ in the regulation of glucose metabolism is suggested by studies showing that loss of the steroid receptor coregulator SRC2 in mice leads to a phenotype similar to von Gierke's disease (glycogen storage disease-1a), a human disorder caused by mutations in the ROR $\alpha$ target gene glucose-6-phosphatase (G6Pase) and associated with severe hypoglycemia and abnormal accumulation of glycogen in the liver. ${ }^{33}$ Interestingly, treatment of hepatocytes with T0901317 repressed the expression of G6Pase and chromatin immunoprecipitation (ChIP re-ChIP), which demonstrated that this synthetic ligand diminishes the presence of SRC2 at the G6Pase promoter in an ROR-dependent fashion. ${ }^{22}$ Consistent with these studies, treatment of HepG2 cells with oxysterols putative endogenous modulators of RORs - resulted in repression of the expression of G6Pase and the displacement of ROR-dependent SRC2 at the G6Pase promoter. ${ }^{34}$ To further support these findings, treatment of murine primary hepatocytes with oxysterols resulted in repression of both PEPCK and G6Pase and resulted in a reduction of glucose output from these cells by $24 \% .{ }^{34}$

All three ROR isoforms bind to the identical response elements, so it is predicted that each receptor can compensate for the other in modulating target gene levels when coexpressed. ROR $\alpha$ and ROR $\gamma$ are both expressed in skeletal muscle, a tissue that accounts for approximately $40 \%$ of total body mass and $50 \%$ of energy expenditure, and in the liver, an organ that is a major site of fatty acid and glucose oxidation. ${ }^{35}$ It has been shown that ROR $\gamma$ controls expression of genes that regulate muscle activity, fat mass, and lipid homeostasis (fatty acid-binding protein 4 [FABP4], CD36, and LPL) and plays a role in the regulation of reactive oxygen species (ROS). ${ }^{36}$ Microarray analyses of liver tissue from $\mathrm{ROR} \alpha^{\mathrm{sg} / \mathrm{sg}}, \mathrm{ROR} \gamma^{-}$, and $\mathrm{ROR} \alpha^{\mathrm{sg} / \mathrm{sg}} / \mathrm{ROR}^{-/}$double knockout mice ${ }^{37}$ revealed that $\operatorname{ROR} \alpha$ and $\operatorname{ROR} \gamma$ are critical regulators of hepatic genes encoding several phase I and phase II metabolic enzymes, including 3 $\beta$-hydroxysteroid dehydrogenases, cytochrome P450 enzymes, and sulfotransferases. Mice deficient in ROR $\gamma$ also exhibit reduced blood glucose levels. ${ }^{37}$ These findings suggest that ROR $\gamma$ may have a role in glucose metabolism, through regulation of adipogenesis and insulin sensitivity. In mice, double knockout of $\operatorname{ROR} \alpha$ and ROR $\gamma$ showed a similar reduction in cholesterol, triglyceride, and blood glucose levels, compared to single gene knockout. Additionally, RORs were shown to affect the expression of several genes involved in steroid, bile acid, and xenobiotic metabolism, suggesting that RORs are promising targets for the treatment of obesityassociated insulin resistance and metabolic disease. ${ }^{37,38}$ As muscle and liver are critical mediators of insulin sensitivity, lipid metabolism, and energy balance, ${ }^{39,40}$ targeting ROR $\alpha$ and ROR $\gamma$ for the treatment of metabolic disease holds great promise.

\section{RORs in autoimmunity}

The T-cell-specific ROR $\gamma$ isoform, ROR $\gamma$ t, is the key lineagedefining transcription factor for the differentiation program of Th17 cells. ${ }^{41}$ The Th17 cell, which produces interleukin-17 (IL-17) and IL-22, has been implicated in inflammatory conditions and autoimmune disorders, including arthritis, multiple sclerosis, asthma, and inflammatory bowel disease. ${ }^{42,43}$ Mice lacking IL-17 are resistant to developing experimental autoimmune encephalomyelitis (EAE), a model of multiple sclerosis and collagen-induced arthritis (CIA) a model of rheumatoid arthritis. Furthermore, neutralizing IL-17 with a targeted antibody suppressed autoimmune inflammation, joint damage, and bone destruction. ${ }^{44-46}$ Recently, a study using an adoptive transfer model of colitis revealed the 
importance of ROR $\gamma$ in immunity. In this study, IL-17Anull T cells were transferred to RAG1-null mice, leading to a severe colitis phenotype, similar to mice transferred with wild-type T cells. However, transfer of ROR $\gamma$-null T cells into these mice failed to increase mucosal IL-17 cytokine levels, and induction of colitis was not detected. Subsequent treatment of these animals with IL-17 resulted in induction of colitis. ${ }^{47}$ Consequently, $\mathrm{RAG} 1^{-/-}$mice reconstituted with bone marrow cells from $\operatorname{ROR} \alpha$ or $\operatorname{ROR} \gamma$-deficient mice were shown to be less susceptible to EAE than mice reconstituted with wild-type bone marrow. ${ }^{48}$ These data are consistent with earlier work showing that ROR $\alpha$ and ROR $\gamma$ (but not ROR $\beta$ ) are expressed in bone marrow-derived mesenchymal stem cells. ${ }^{49}$ Combined, these observations suggest that controlling Th17 differentiation and IL-17 expression is important to the prevention of autoimmune disorders. Consequently, inhibition of ROR $\gamma$ function offers a potential therapeutic target for the treatment of immune disorders such as rheumatoid arthritis, multiple sclerosis, and chronic colitis (Figure 3).

Macrophages are specialized differentiated mononuclear phagocytic cells that perform key roles in antimicrobial defense, autoimmunity, and inflammatory disease. ${ }^{50}$ It has been shown that macrophages can produce IL-17, ${ }^{51}$ and studies have been published exploring the role of RORs in regulating macrophage activation. ${ }^{52}$ In particular, a role for ROR $\alpha$ in macrophages was suggested by studies of ROR $\alpha^{\mathrm{sg} / \mathrm{sg}}$ mice. Following lipopolysaccharide (LPS) stimulation, macrophages from these animals produce more IL- $1 \beta$ and TNF $\alpha$

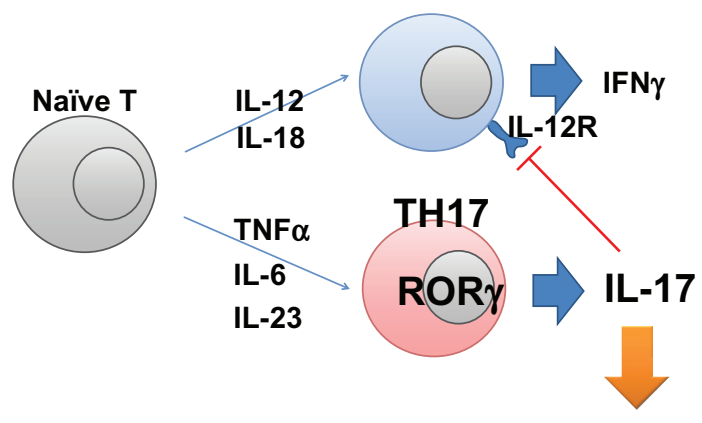

Rheumatoid arthritis (RA)

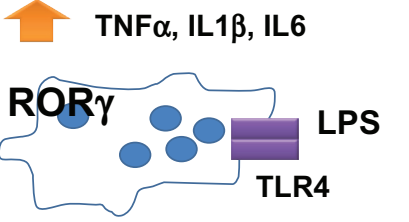

Activated macrophage

Figure 3 Proposed model for ROR $\gamma$ inhibition in rheumatoid arthritis therapy. Abbreviations: IL, interleukin; IFN $\gamma$, interferon gamma; TNFd, tumor necrosis factor alpha; LPS, lipopolysaccharide; TLR4, toll-like receptor 4. than macrophages from control animals. ${ }^{53-55}$ Moreover, overexpression of ROR $\alpha$ in human primary smooth muscle cells inhibits TNF- $\alpha$-induced expression of IL-6, IL-8, and cyclooxygenase-2 (COX-2), and up-regulates IкB. ${ }^{56}$ Induction of I $\mathrm{B}$ following LPS exposure has been suggested to be involved in the downregulation of cytokine/chemokine expression..$^{57,58}$ These studies suggest that ROR $\alpha$ may be a negative regulator of proinflammatory cytokine production in endotoxin-primed macrophages. Comprehensive geneexpression profiling using quantitative PCR revealed that ROR $\alpha$ and ROR $\gamma$ but not ROR $\beta$ are expressed in resting macrophages. Eight hours post-LPS treatment, the expression of all three ROR isoforms was increased significantly. ${ }^{59}$ Similar to LPS, interferon gamma (IFN $\gamma$ ) is a classic macrophage activator. IFN $\gamma$ binding to its cognate receptor results in increased expression of major histocompatibility complex class II (MHC), the chemokine receptor CCR2, and the toll-like receptors TLR2 and TLR4. LPS stimulation of IFN $\gamma$-primed macrophages results in increased secretion of the antimicrobial cytokines IL6 and TNF $\alpha$ as well as nitric oxide. Interestingly, the expression of ROR $\alpha$ peaks at just one hour post-stimulation with the IFN- $\gamma$, which is significantly earlier than the expression peak of $>20$ hours observed post-LPS exposure. This stimulus-dependent expression profile demonstrates that monitoring ROR expression can serve as a dynamic marker of macrophage activation. LPS stimulation of macrophages enhances autoimmune response through activation of toll-like receptor (TLR) signaling, and mice deficient in either TLR2 or TLR4 are resistant to CIA and streptococcal-cell-wall-induced arthritis. ${ }^{60}$ Studies also suggest that RORs regulate the stimulation of macrophages by regulating NF- $\mathrm{KB}$ signaling, a pathway triggered by LPS exposure. ${ }^{55,56}$ Consequently, these findings suggest that targeted inhibition of ROR $\alpha$ or ROR $\gamma$ with synthetic ligands could provide a means for reducing autoimmune pathology (Figure 3).

\section{Ligand modulation of RORs}

As shown in Table 1, several putative endogenous and synthetic ligands have been described for the RORs. The synthetic LXR, PXR, FXR agonist T0901317 was shown to repress both $\operatorname{ROR} \alpha$ and $\operatorname{ROR} \gamma,{ }^{22,61}$ and this compound has demonstrated therapeutic potential in the CIA model. ${ }^{62}$ However, in this study, it was not clear whether the compound's efficacy was due to repression of $\operatorname{ROR} \alpha$ and ROR $\gamma$ or if the activation of LXR played a role. Medicinal chemistry efforts focused on the T0901317 scaffold led to the development of several nonsterol, nonnatural-product 
Table I Natural and synthetic ligands of $R O R \alpha$ and $R O R \gamma$

\begin{tabular}{|c|c|c|c|c|c|}
\hline Name & Pharmacology & Origin & $\begin{array}{l}\operatorname{ROR} \alpha \\
\mathrm{IC}_{50}(\mu \mathrm{M})\end{array}$ & $\begin{array}{l}\text { ROR } \gamma \\
I^{I C} C_{50}(\mu M)\end{array}$ & PMID \\
\hline $\begin{array}{l}\text { 7-Hydroxy } \\
\text { cholesterols }\end{array}$ & $\begin{array}{l}\text { Endogenous } R O R \alpha / \\
\text { ROR } \gamma \text { ligand }\end{array}$ & $\begin{array}{l}\text { Screen of } \\
\text { Oxysterols } \\
\text { for ROR activity }\end{array}$ & 0.162 & $\begin{array}{l}\text { EC50: } \\
0.02-0.04\end{array}$ & $\begin{array}{l}20203100 \\
21297105\end{array}$ \\
\hline Ursolic acid & $\mathrm{ROR} \gamma$ inverse agonist & Plants & NR (not reported) & 0.68 & 21566134 \\
\hline Digoxin & $\mathrm{ROR} \gamma$ inverse agonist & Foxglove plant & No inhibitory effect & 1.98 & 21441909 \\
\hline T0901317 & $\begin{array}{l}\text { RORs: inverse agonist } \\
\text { LXR, PXR, FXR: } \\
\text { agonist }\end{array}$ & $\begin{array}{l}\text { Human NR } \\
\text { specific } \\
\text { screen }\end{array}$ & 0.132 & 0.051 & $\begin{array}{l}19887649 \\
21735608\end{array}$ \\
\hline SRI078 & $\begin{array}{l}\text { ROR } \alpha / R O R \gamma \\
\text { agonist }\end{array}$ & $\begin{array}{l}\text { Synthetic } \\
\text { Small-molecule } \\
\text { Analog of T090131 }\end{array}$ & $1-3$ & $\mathrm{I}-3$ & $\begin{array}{l}20735016 \\
22509368\end{array}$ \\
\hline SRI00I & $\begin{array}{l}\mathrm{ROR} \alpha / \mathrm{ROR} \gamma \\
\text { inverse agonist }\end{array}$ & $\begin{array}{l}\text { Synthetic } \\
\text { Small-molecule } \\
\text { Analog of T090131 }\end{array}$ & 0.172 & 0.111 & 21499262 \\
\hline SR3335 & $\begin{array}{l}\mathrm{ROR} \alpha \\
\text { inverse agonist }\end{array}$ & $\begin{array}{l}\text { Synthetic } \\
\text { Small-molecule } \\
\text { Analog of T090 I3I }\end{array}$ & 0.480 & No effect & 21090593 \\
\hline SR22II & $\begin{array}{l}\text { ROR } \gamma \\
\text { inverse agonist }\end{array}$ & $\begin{array}{l}\text { Synthetic } \\
\text { Small-molecule } \\
\text { Analog of T090131 }\end{array}$ & $\begin{array}{l}>10 \mu \mathrm{M} \text { (no effect on } \\
\text { RORa transcriptional } \\
\text { activity at } 10 \mu \mathrm{M} \text { ) }\end{array}$ & approx. 0.320 & 22292739 \\
\hline SRI555 & $\begin{array}{l}\text { ROR } \gamma \\
\text { inverse agonist }\end{array}$ & $\begin{array}{l}\text { Synthetic } \\
\text { Small-molecule } \\
\text { Analog of T090131 }\end{array}$ & No effect & approx. 1.5 & 22769242 \\
\hline
\end{tabular}

ROR-selective modulators. All of the Scripps Research (SR) analogs of T0901317 described below were shown to be devoid of LXR binding and agonism. SR3335 was identified as an inverse agonist of ROR $\alpha$ with little effect on $\mathrm{ROR} \gamma .{ }^{23}$ It is reported to suppress the expression of ROR $\alpha$ target genes involved in hepatic gluconeogenesis, such as G6Pase (G6P) and phosphoenolpyruvate carboxykinase 2 $(P C K 2) .{ }^{23}$ The dual ROR $\alpha / \mathrm{ROR} \gamma$ inverse agonist SR1001 and the ROR $\gamma$-selective inverse agonist SR2211 demonstrated inhibition of inflammatory cytokine expression, particularly IL17. SR1001 was shown to be efficacious in the EAE model in rodents. ${ }^{23}$ More recently, the ROR $\gamma$ selective inverse agonist SR1555 was shown to positively modulate Tregs. ${ }^{25}$ These studies strongly suggest that inhibition of the RORs has potential therapeutic value for the treatment of Th17-derived autoimmune diseases such as multiple sclerosis and rheumatoid arthritis.

\section{Structural insights into modulation of RORs}

The first atomic structure of an ROR LBD to be solved was that of ROR $\beta$ bound with stearic acid. ${ }^{21}$ Subsequently, alltrans retinoic acid (ATRA) and a synthetic analog (ALRT 1550) were identified as putative functional ligands, and their binding mechanisms were shown using crystal structures. ${ }^{63}$
Interestingly, there have been no follow-up publications on these putative ROR $\beta$ ligands. The characterization of the ROR $\alpha$ LBD structure identified cholesterol and cholesterol sulfate as potential ligands and implicated ROR $\alpha$ in lipid metabolism. ${ }^{18,19}$ In spite of the high sequence similarity (63\%) and similarly sized ligand-binding pockets $\left(722 \AA^{3}\right.$ and $766 \AA^{3}$, respectively; Table 2) of the LBDs of ROR $\alpha$ LBD and ROR $\beta$, cholesterol has no effect on ROR $\beta$ activity. ${ }^{63}$

Within the past few years, the crystal structure of ROR $\gamma$ with oxysterols (20 $\alpha \mathrm{OHC}, 22 \mathrm{R}-\mathrm{OHC}$, and 25-OHC) as agonists and of digoxin as antagonist or inverse agonist ${ }^{64}$ were solved by two separate groups. Comparison of these two structures provided important insights into the agonist and antagonist modes of ligand binding. Agonist (25-OHC)bound ROR $\gamma$ positions its AF2 helix (helix 12) in a conformation that facilitates coactivator binding by a conserved-charge clamp groove involving helices $3,4,5$, and $12 .{ }^{20}$ In contrast, antagonism (digoxin) results from disruption of the active conformation of the highly dynamic AF2 helix. Occupying the same cavity as the agonist, digoxin interferes with the key cation- $\pi$ interaction between residues of helix 11 and 12 . In addition, the large extension of the digoxin molecule sterically hinders formation of a proper LBD-coactivator interface necessary for functional activation. This critical positioning of the AF2 helix in either agonist or antagonist 
Table 2 List of ROR X-ray crystal structures in the PDB database

\begin{tabular}{|c|c|c|c|c|c|}
\hline $\begin{array}{l}\text { Protein } \\
\text { isoform }\end{array}$ & Resolution/PDB ID & Peptide & LBD pocket size & Ligand identified & Reference \\
\hline ROR $\beta$ & $1.9 / 1 \mathrm{~K} 4 \mathrm{~W}$ & SRC-I & $766 \AA^{3}$ & Stearic acid & 21 \\
\hline $\operatorname{ROR} \alpha$ & I.63/1 N83 & - & $722 \AA^{3}$ & Cholesterol & 19 \\
\hline $\operatorname{ROR} \beta$ & $2.1 / I N 4 \mathrm{H}$ & SRC-I & $753 \AA^{3}$ & All-trans retinoic acid & 63 \\
\hline $\operatorname{ROR} \beta$ & I.5/IN4Q7 & SRC-I & $820 \AA^{3}$ & $\begin{array}{l}\text { 7-(3,5-ditert-butylphenyl)-3-methylocta- } \\
\text { 2,4,6-trienoic acid }\end{array}$ & 63 \\
\hline $\mathrm{ROR} \alpha$ & $2.2 / 15 O X$ & - & ND & Cholest-5-en-3-yl hydrogen sulfate & 18 \\
\hline $\mathrm{ROR} \gamma$ & $2.35 / 3 \mathrm{KYT}$ & SCR2-2 & ND & 20-hydroxycholesterol & 20 \\
\hline $\mathrm{ROR} \gamma$ & $2.4 / 3 \mathrm{LOJ}$ & SCR2-2 & ND & (3alpha,8alpha,22R)-cholest-5-ene-3,22-dio & 20 \\
\hline $\mathrm{ROR} \gamma$ & I.74/3LOL & SCR2-2 & ND & 25-hydroxycholesterol & 20 \\
\hline $\operatorname{ROR} \gamma$ & $2.2 / 3 \mathrm{BOW}$ & - & ND & Digoxin & 64 \\
\hline
\end{tabular}

Abbreviation: ND, not determined; LBD, ligan binding domain; PDB ID, protein data bank identifier.

mode, resulting in coactivator or corepressor binding, has been reported for other nuclear receptors. ${ }^{65,66}$

It will be interesting to see if a structure-based design will lead to the improved potency and selectivity of agonists and antagonists of the RORs with the predicted biological outcomes. Lusher et al showed that the extent of antagonism (partial or full) for a set of chemically related progesteronereceptor modulators depended on the degree of disruption of interaction with a critical methionine (AA 909) residue on helix $12 .{ }^{66}$ Thus, it is likely that the structure-guided optimization of synthetic ligands can facilitate the development of potent and isoform-selective ROR modulators with targeted tissue activity that avoids unwanted side effects.

\section{Concluding remarks}

A number of small molecule ligands for ROR $\alpha$ and ROR $\gamma$ have been reported in recent years, highlighting the potential for this NR subfamily as a therapeutic drug target in metabolic disease. Recent animal studies have indicated that compounds that repress the RORs also suppress Th17-cell development and offer efficacy in models of autoimmunity. Several studies suggest that such compounds may also inhibit proinflammatory genes in activated macrophages. Although further optimization of these small molecule ligands is required, it is clear that targeting RORs for the treatment of Th17-mediated immune disorders may serve as appropriate therapy and avoid the side-effect profile of current clinically used immunosuppressants. It has been shown that the ROR isoform, ROR $\gamma$ t, plays a critical function in thymic T-cell (helper and cytotoxic T cells) survival, which is critical for Th17-cell differentiation. Ideally one would like to selectively target ROR $\gamma$ t for use in treatment of autoimmune disease; however, these receptors share identical LBD domains and differ only slightly on their N-termini, making it unlikely that selective modulators of ROR $\gamma t$ can be developed. Regardless, chemical probes that are pure isoform-selective activators or repressors will provide a means to fully dissect the biology of the ROR isoforms.

\section{Disclosure}

The authors report no conflicts of interest in this work.

\section{References}

1. Evans RM. The steroid and thyroid hormone receptor superfamily. Science. 1988;240(4854):889-895.

2. Jetten AM, Kurebayashi S, Ueda E. The ROR nuclear orphan receptor subfamily: critical regulators of multiple biological processes. Prog Nucleic Acid Res Mol Biol. 2001;69:205-247.

3. Wang Y, Kumar N, Crumbley C, Griffin PR, Burris TP. A second class of nuclear receptors for oxysterols: Regulation of RORalpha and RORgamma activity by 24S-hydroxycholesterol (cerebrosterol). Biochim Biophys Acta. 2010;1801(8):917-923.

4. Aranda A, Pascual A. Nuclear hormone receptors and gene expression. Physiol Rev. 2001;81(3):1269-1304.

5. Becker-Andre M, Andre E, DeLamarter JF. Identification of nuclear receptor mRNAs by RT-PCR amplification of conserved zincfinger motif sequences. Biochem Biophys Res Commun. 1993;194(3): 1371-1379.

6. Carlberg C, Hooft van Huijsduijnen R, Staple JK, DeLamarter JF, Becker-Andre M. RZRs, a new family of retinoid-related orphan receptors that function as both monomers and homodimers. Mol Endocrinol. 1994;8(6):757-770.

7. Hirose T, Smith RJ, Jetten AM. ROR gamma: the third member of ROR/RZR orphan receptor subfamily that is highly expressed in skeletal muscle. Biochem Biophys Res Commun. 1994;205(3): 1976-1983.

8. Hamilton BA, Frankel WN, Kerrebrock AW, et al. Disruption of the nuclear hormone receptor RORalpha in staggerer mice. Nature. 1996;379(6567):736-739.

9. Schaeren-Wiemers N, Andre E, Kapfhammer JP, Becker-Andre M. The expression pattern of the orphan nuclear receptor RORbeta in the developing and adult rat nervous system suggests a role in the processing of sensory information and in circadian rhythm. Eur J Neurosci. 1997;9(12):2687-2701.

10. Giguere V, Tini M, Flock G, Ong E, Evans RM, Otulakowski G. Isoform-specific amino-terminal domains dictate DNA-binding properties of ROR alpha, a novel family of orphan hormone nuclear receptors. Genes Dev. 1994;8(5):538-553. 
11. Xie H, Sadim MS, Sun Z. RORgammat recruits steroid receptor coactivators to ensure thymocyte survival. J Immunol. 2005;175(6): 3800-3809.

12. Atkins GB, Hu X, Guenther MG, Rachez C, Freedman LP, Lazar MA. Coactivators for the orphan nuclear receptor RORalpha. Mol Endocrinol. 1999;13(9):1550-1557.

13. Liu C, Li S, Liu T, Borjigin J, Lin JD. Transcriptional coactivator PGC-1alpha integrates the mammalian clock and energy metabolism. Nature. 2007;447(7143):477-481.

14. Yin L, Lazar MA. The orphan nuclear receptor Rev-erbalpha recruits the $\mathrm{N}-\mathrm{CoR} / \mathrm{histone}$ deacetylase 3 corepressor to regulate the circadian Bmal1 gene. Mol Endocrinol. 2005;19(6):1452-1459.

15. Poliandri AH, Gamsby JJ, Christian M, et al. Modulation of clock gene expression by the transcriptional coregulator receptor interacting protein 140 (RIP140). J Biol Rhythms. 2011;26(3):187-199.

16. Greiner EF, Kirfel J, Greschik H, et al. Differential ligand-dependent protein-protein interactions between nuclear receptors and a neuronal-specific cofactor. Proc Natl Acad Sci U S A. 2000;97(13): 7160-7165.

17. Harris JM, Lau P, Chen SL, Muscat GE. Characterization of the retinoid orphan-related receptor-alpha coactivator binding interface: a structural basis for ligand-independent transcription. Mol Endocrinol. 2002;16(5):998-1012.

18. Kallen J, Schlaeppi JM, Bitsch F, Delhon I, Fournier B. Crystal structure of the human RORalpha ligand-binding domain in complex with cholesterol sulfate at 2.2 A. J Biol Chem. 2004;279(14):14033-14038.

19. Kallen JA, Schlaeppi JM, Bitsch F, et al. X-ray structure of the hRORalpha LBD at $1.63 \mathrm{~A}$ : structural and functional data that cholesterol or a cholesterol derivative is the natural ligand of RORalpha. Structure. 2002;10(12):1697-1707.

20. Jin L, Martynowski D, Zheng S, Wada T, Xie W, Li Y. Structural basis for hydroxycholesterols as natural ligands of orphan nuclear receptor RORgamma. Mol Endocrinol. 2010;24(5):923-929.

21. Stehlin C, Wurtz JM, Steinmetz A, et al. X-ray structure of the orphan nuclear receptor RORbeta ligand-binding domain in the active conformation. EMBO J. 2001;20(21):5822-5831.

22. Kumar N, Solt LA, Conkright JJ, et al. The benzenesulfoamide T0901317[N-(2,2,2-trifluoroethyl)-N-[4-[2,2,2-trifluoro-1-hydroxy-1(trifluoromethyl)ethy 1]phenyl]-benzenesulfonamide] is a novel retinoic acid receptor-related orphan receptor-alpha/gamma inverse agonist. $M o l$ Pharmacol. 2010;77(2):228-236.

23. Kumar N, Kojetin DJ, Solt LA, et al. Identification of SR3335 (ML-176): a synthetic RORalpha selective inverse agonist. ACS Chem Biol. 2011;6(3):218-222.

24. Solt LA, Kumar N, Nuhant P, et al. Suppression of TH17 differentiation and autoimmunity by a synthetic ROR ligand. Nature. 2011;472(7344):491-494.

25. Solt LA, Kumar N, He Y, Kamenecka TM, Griffin PR, Burris TP. Identification of a selective RORgamma ligand that suppresses T(H)17 cells and stimulates T regulatory cells. ACS Chem Biol. 2012.

26. Kumar N, Lyda B, Chang MR, et al. Identification of SR2211: a potent synthetic RORgamma-selective modulator. ACS Chem Biol. 2012;7(4):672-677.

27. Huh JR, Leung MW, Huang P, et al. Digoxin and its derivatives suppress TH17 cell differentiation by antagonizing RORgammat activity. Nature. 2011;472(7344):486-490.

28. Xu T, Wang X, Zhong B, Nurieva RI, Ding S, Dong C. Ursolic acid suppresses interleukin-17 (IL-17) production by selectively antagonizing the function of RORgamma t protein. $J$ Biol Chem. 2011;286(26):22707-22710

29. Kassi E, Sourlingas TG, Spiliotaki M, et al. Ursolic acid triggers apoptosis and Bcl-2 downregulation in MCF-7 breast cancer cells. Cancer Invest. 2009;27(7):723-733.

30. Cha HJ, Park MT, Chung HY, et al. Ursolic acid-induced downregulation of MMP-9 gene is mediated through the nuclear translocation of glucocorticoid receptor in HT1080 human fibrosarcoma cells. Oncogene. 1998;16(6):771-778.
31. Andre E, Conquet F, Steinmayr M, Stratton SC, Porciatti V, BeckerAndre M. Disruption of retinoid-related orphan receptor beta changes circadian behavior, causes retinal degeneration and leads to vacillans phenotype in mice. EMBO J. 1998;17(14):3867-3877.

32. Matysiak-Scholze U, Nehls M. The structural integrity of ROR alpha isoforms is mutated in staggerer mice: cerebellar coexpression of ROR alpha1 and ROR alpha4. Genomics. 1997;43(1):78-84.

33. Chopra AR, Louet JF, Saha P, et al. Absence of the SRC-2 coactivator results in a glycogenopathy resembling Von Gierke's disease. Science. 2008;322(5906):1395-1399.

34. Wang Y, Kumar N, Solt LA, et al. Modulation of retinoic acid receptorrelated orphan receptor alpha and gamma activity by 7-oxygenated sterol ligands. J Biol Chem. 2010;285(7):5013-5025.

35. Rasmussen BB, Wolfe RR. Regulation of fatty acid oxidation in skeletal muscle. Anпи Rev Nutr. 1999;19:463-484.

36. Raichur S, Lau P, Staels B, Muscat GE. Retinoid-related orphan receptor gamma regulates several genes that control metabolism in skeletal muscle cells: links to modulation of reactive oxygen species production. $J$ Mol Endocrinol. 2007;39(1):29-44.

37. Kang HS, Angers M, Beak JY, et al. Gene expression profiling reveals a regulatory role for ROR alpha and ROR gamma in phase I and phase II metabolism. Physiol Genomics. 2007;31(2):281-294.

38. Meissburger B, Ukropec J, Roeder E, et al. Adipogenesis and insulin sensitivity in obesity are regulated by retinoid-related orphan receptor gamma. EMBO Mol Med. 2011;3(11):637-651.

39. Lau P, Nixon SJ, Parton RG, Muscat GE. RORalpha regulates the expression of genes involved in lipid homeostasis in skeletal muscle cells: caveolin-3 and CPT-1 are direct targets of ROR. J Biol Chem. 2004;279(35):36828-36840.

40. Ramakrishnan SN, Lau P, Burke LJ, Muscat GE. Rev-erbbeta regulates the expression of genes involved in lipid absorption in skeletal muscle cells: evidence for cross-talk between orphan nuclear receptors and myokines. J Biol Chem. 2005;280(10):8651-8659.

41. Ivanov II, McKenzie BS, Zhou L, et al. The orphan nuclear receptor RORgammat directs the differentiation program of proinflammatory IL-17+ T helper cells. Cell. 2006;126(6):1121-1133.

42. Huang Z, Xie H, Wang R, Sun Z. Retinoid-related orphan receptor gamma $t$ is a potential therapeutic target for controlling inflammatory autoimmunity. Expert Opin Ther Targets. 2007;11(6): 737-743.

43. Ivanov II, Zhou L, Littman DR. Transcriptional regulation of Th17 cell differentiation. Semin Immunol. 2007;19(6):409-417.

44. Lubberts E, Koenders MI, Oppers-Walgreen B, et al. Treatment with a neutralizing anti-murine interleukin-17 antibody after the onset of collagen-induced arthritis reduces joint inflammation, cartilage destruction, and bone erosion. Arthritis Rheum. 2004;50(2):650-659.

45. Stockinger B, Veldhoen M, Martin B. Th17 T cells: linking innate and adaptive immunity. Semin Immunol. 2007;19(6):353-361.

46. Furuzawa-Carballeda J, Vargas-Rojas MI, Cabral AR. Autoimmune inflammation from the Th17 perspective. Autoimmun Rev. 2007;6(3): 169-175.

47. Leppkes $M$, Becker $C$, Ivanov II, et al. RORgamma-expressing Th17 cells induce murine chronic intestinal inflammation via redundant effects of IL-17A and IL-17F. Gastroenterology. 2009;136(1):257-267.

48. Yang XO, Chang SH, Park H, et al. Regulation of inflammatory responses by IL-17F. Journal Exp Med. 2008;205(5):1063-1075.

49. Meyer T, Kneissel M, Mariani J, Fournier B. In vitro and in vivo evidence for orphan nuclear receptor RORalpha function in bone metabolism. Proc Natl Acad Sci U S A. 2000;97(16):9197-9202.

50. Fujiwara N, Kobayashi K. Macrophages in inflammation. Curr Drug Targets. Inflammation and Allergy. 2005;4(3):281-286.

51. Song C, Luo L, Lei Z, et al. IL-17-producing alveolar macrophages mediate allergic lung inflammation related to asthma. J Immunol. 2008;181(9): 6117-6124.

52. Gu Y, Yang J, Ouyang X, et al. Interleukin 10 suppresses Th17 cytokines secreted by macrophages and T cells. Eur J Immunol. 2008;38(7): $1807-1813$ 
53. Bakalian A, Kopmels B, Messer A, et al. Peripheral macrophage abnormalities in mutant mice with spinocerebellar degeneration. Res Immunol. 1992;143(1):129-139.

54. Kopmels B, Mariani J, Delhaye-Bouchaud N, Audibert F, Fradelizi D, Wollman EE. Evidence for a hyperexcitability state of staggerer mutant mice macrophages. J Neurochem. 1992;58(1):192-199.

55. Stapleton CM, Jaradat M, Dixon D, et al. Enhanced susceptibility of staggerer (RORalphasg/sg) mice to lipopolysaccharide-induced lung inflammation. Am J Physiol Lung Cell Mol Physiol. 2005;289(1): L144-L152.

56. Delerive P, Monte D, Dubois G, et al. The orphan nuclear receptor ROR alpha is a negative regulator of the inflammatory response. EMBO Rep. 2001;2(1):42-48.

57. Hawiger J. Innate immunity and inflammation: a transcriptional paradigm. Immunol Res. 2001;23(2-3):99-109.

58. Karin M, Delhase M. The I kappa B kinase (IKK) and NF-kappa B: key elements of proinflammatory signalling. Semin Immunol. 2000; 12(1):85-98.

59. Barish GD, Downes M, Alaynick WA, et al. A Nuclear Receptor Atlas: macrophage activation. Mol Endocrinol. 2005;19(10):2466-2477.

60. Joosten LA, Koenders MI, Smeets RL, et al. Toll-like receptor 2 pathway drives streptococcal cell wall-induced joint inflammation: critical role of myeloid differentiation factor 88. J Immunol. 2003;171(11): 6145-6153.
61. Mitro N, Vargas L, Romeo R, Koder A, Saez E. T0901317 is a potent PXR ligand: implications for the biology ascribed to LXR. FEBS Lett. 2007;581(9):1721-1726.

62. Chintalacharuvu SR, Sandusky GE, Burris TP, Burmer GC, Nagpal S. Liver $\mathrm{X}$ receptor is a therapeutic target in collagen-induced arthritis. Arthritis Rheum. 2007;56(4):1365-1367.

63. Stehlin-Gaon C, Willmann D, Zeyer D, et al. All-trans retinoic acid is a ligand for the orphan nuclear receptor ROR beta. Nat Struct Biol. 2003;10(10):820-825.

64. Fujita-Sato S, Ito S, Isobe T, et al. Structural basis of digoxin that antagonizes RORgamma t receptor activity and suppresses Th17 cell differentiation and interleukin (IL)-17 production. J Biol Chem. September 9, 2011;286(36):31409-31417.

65. Xu HE, Stanley TB, Montana VG, et al. Structural basis for antagonistmediated recruitment of nuclear co-repressors by PPARalpha. Nature. 2002;415(6873):813-817.

66. Lusher SJ, Raaijmakers HC, Vu-Pham D, et al. Structural basis for agonism and antagonism for a set of chemically related progesterone receptor modulators. J Biol Chem. 2011;286(40):35079-35086.
Journal of Experimental Pharmacology

\section{Publish your work in this journal}

The Journal of Experimental Pharmacology is an international, peerreviewed, open access journal publishing original research, reports, reviews and commentaries on all areas of laboratory and experimental pharmacology. The manuscript management system is completely online and includes a very quick and fair peer-review system.

\section{Dovepress}

Visit http://www.dovepress.com/testimonials.php to read real quotes from published authors. 